\title{
印旛沼における底泥巻き上げ，湖底の光環境と 水生植物との相互関係 \\ RELATIONSHIP BETWEEN BOTTOM SEDIMENTS RESUSPENSION, LIGHT CONDITION, AND AQUATIC MACROPHYTES IN INBA MARSH
}

\author{
天野 邦彦1 ・時岡 利和2 \\ Kunihiko AMANO and Toshikazu TOKIOKA \\ 1正会員 工博 （独）土木研究所 河川生態チーム 上席研究員（テ305-8516 つくば市南原 $1-6$ ) \\ 2正会員（独）土木研究所 河川生態チーム 研究員（†305-8516 つくば市南原 1-6）
}

\begin{abstract}
Suppression effect on bottom sediments resuspension by aquatic macrophyte Trapa in Inba marsh was shown by field measurement and numerical simulation. Temperature, turbidity, $\mathrm{pH}$, dissolved oxygen and electric conductivity were measured in- and outside of the Trapa vegetation area. While vegetation was dense, turbidity measured inside of it was lower because of the wave attenuation by vegetation. This leads to less sediment resuspension. Another conspicuous difference was found in dissolved oxygen variation. Dissolved oxygen in the water column beneath the canopy of Trapa was lower maybe because of limited gas exchange at water surface. Suppressed resuspension by vegetation will enhance the irradiance at the bottom of the marsh. This will improve the chance for submersed macrophytes to survive. If we can rehabilitate submersed macrophytes to Inba marsh, they will keep suitable environment by themselves. Improving light condition will be the key to the rehabilitation of submersed macrophytes.
\end{abstract}

Key Words : Resuspension, bottom sediments, submersed plant, light, turbidity

\section{1. はじめに}

我が国における湖沼の環境問題は，多くの場合流域か らの栄養塩類流入負荷量の増大に伴い進行した富栄養化 による水質悪化に注目寸ることが多い. 昭和 59 年の湖 沼水質対策特別措置法の制定などを契機に，富栄養化に よる湖沼環境の悪化一の対策が流域からの負荷削減を中 心に進められた結果，諏訪湖のように水質改善が見られ， 同時に湖沼の生態系にも変化が起こってきている湖沼も 見受けられる. その反面，霞ヶ浦のように統計量からは 流域からのリン流入負荷量は減っているように思われる ものの, 湖内のリン濃度が漸増している湖沼もある. 霞ヶ浦では無機態のリン, 窒素が水柱で枯渇していない にもかかわらず，一次生産が減少しているという指摘も あり，湖沼水質と湖沼生態系は，密接に関連しながらも， その関係は単純なものではない.

従来, 湖沼水質及び生態系を解析寸るために, 栄養塩 類濃度, 一次生産者である植物プランクトン, その捕食 者である動物プランクトン，魚類間の相互関係を動的に 解析するモデルが開発されてきている. このようなモデ
ルの多くは，それぞれの栄養レベルの要素間の相互作用 を捕食一被食関係により記述することにより炭素，窒素， リンといった生元素の物質収支を表して, さらに要素毎 の変化量を, 増殖や死滅速度をモデル化することで, 生 態系要素の量的な変動を計算すると共に, 水質の変動を 解析する．このように湖沼における流動，熱収支，物質 収支を動的に解析して湖沼生態系の変動特性を記述寸る 従来のシミュレーションモデルにおいては，生態系の構 成要素である生物は，湖沼水中の物質循環に変化を与え ることで湖沼の環境に影響を与える形で組み込まれてい ることが多かった.

しかし，生物のもつ環境機能には種々のものがあり， 湖沼の物理環境にも影響を与えることがある. 特に湖沼 水質と生態系との関係のなかでも, 浅い湖沼における植 生の役割についての関心が高まってきている．水質污濁 が進行する前の浅い湖沼においては，多くの水生植物が 繁茂し，透明度の高い水を蓄えていたことが示されてい る. しかし水質污濁の進行は, 湖水を濁らせて, 沈水植 物を減少させる結果となる。 また, 栄養塩類濃度の上昇 に伴い，大型植物量は増加する上に水柱全体あるいは水 面付近に集中寸る ${ }^{1)}$ 。このような状況は漁業やレクリ 
エーション利用の観点から問題視されることが多く，こ のため水草が刈り取られることが多い.このような場合 には, 植物プランクトンの増大と底泥の巻き上げ増加に より湖沼の濁りはさらに上昇し, 光条件の亜化により植 生を破壊してしまう場合もある ${ }^{1)}$. このような状況に 達すると, たとえ流入水質が改善されても底泥からの栄 養塩類の回帰により植物プランクトンの量は減少しない 上に底泥の巻き上げにより濁ったままの状態が続くこと になり，湖沼の環境修復は困難なものになる.

本研究では，上記のようにScheffer ${ }^{1)}$ が指摘したも のと同様の環境変化を経ている印旛沼を対象に大型水生 植物がもつ底泥巻き上げの抑制という機能について現地 調査とシミュレーションを併用して検討を行う。これに より，底泥の巻き上げという浅い湖沼において重要な水 質規定過程に，湖沼生態系の要素である大型水生植物が どの程度影響するのかという環境機能を定量的に評価し， 浅い湖沼の環境修復を進める上で水生植物群落の修復が どの様な影響を持ちうるのかについて考察を行うと共に 過去の状況について推定するものである.

\section{2. 研究方法}

印旛沼においては，干拓事業という大きな改変の後, 高度成長期における水質污濁の進行に伴う水生植物の減 衰を経て, 流域における下水道事業の伸展などに伴う流 入河川水質の改善が見られている. しかし, 沼内の水質 改善は進まず, 水生植物についても, 刈り取りなどの人 為的インパクトを受けながら変遷し, 現在では沼周囲の 抽水植物帯と浮葉植物のオニビシ群落を除き減衰したま まである.

本研究では，まず，印旛沼における水質と水生植物の 変遷について既往資料に基づき整理した．また，水生植 物が沼内水質に与える影響として底泥巻き上げの抑制に 着目し, 現地に残存するオニビシ群落内外において連続 水質観測を行い，シミュレーションモデルによる観測結 果の検証を行った. 以下に, 研究方法について示す.

\section{（1） 現地概要}

現在の印旛沼（千葉県）は，図一1の左下に位置する 西沼と右上に位置する北沼, 及びこれらを結ぶ捷水路か らなっている. 主要な流入河川は, 西沼南東端から流入 する鹿島川（流入直前に高崎川と合流している），西沼 西端から阿宗橋を経て流入する桑納川（流入直前に神崎 川，新川と合流している）が挙げられる，また，北沼は 図中上端に位置する河川により利根川と接続している. これは酒直機場, 印旛機場の 2 つ水門により流動が管 理されており，印旛沼水位が高い場合は，利根川へ印旛 沼水を放流しているほか，印旛沼水位が低い場合には， 利根川からの取水が行われている. また，新川上流には
大和田機場というポンプ施設があり, 出水時に印旛沼水 位が上昇した際には，新川を経て東京湾へ出水の放流を 行うことが可能である. また, 灌䄽, 工業用水, 水道水 の取水量が大きく, 取水による直接利用が印旛沼の水循 環に大きな影響を与えているのが特徵である.

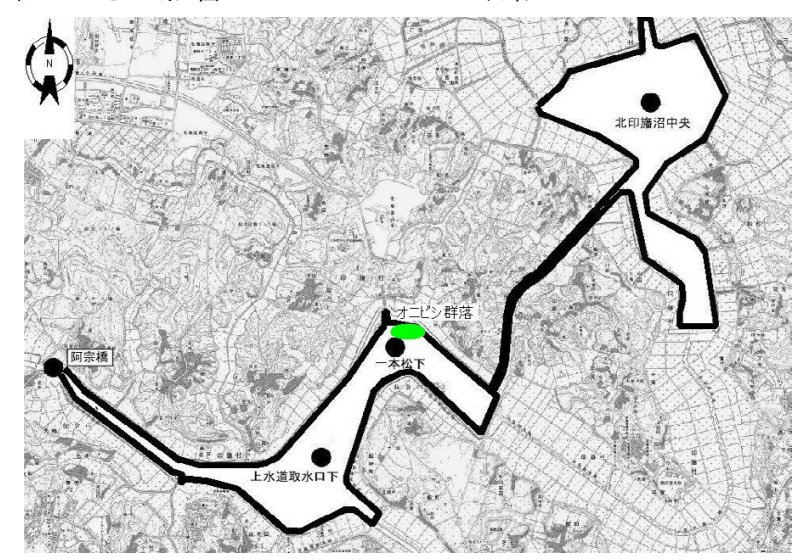

図—1 印旛沼平面図および水質調査地点

現在の印旛沼および流域特性は，表一 1 に示すとおり である. 特徵としては，流域人口が多く，下水道も完全 に普及していないことから，流入河川の平均的水質は全 リンで0. $1(\mathrm{mg} / \mathrm{l})$, 全窒素で3. $0(\mathrm{mg} / \mathrm{l})$ 程度であること から，生産性が高く，富栄養化した湖沼である。しかし， 水深が浅いことから水中では底層でも貧酸素化すること はない.

表一1 現在の印旛沼および流域特性

\begin{tabular}{|c|c|}
\hline 平面積 $\left(\mathrm{km}^{2}\right)$ & 11.55 \\
\hline 容量 $\left(\mathrm{m}^{3}\right)$ & $27,700,000$ \\
\hline 周囲長 $(\mathrm{km})$ & 38 \\
\hline 水深 $(\mathrm{m})$ & Max. 2.5, Ave. 1.7 \\
\hline 平均滞留時間 $($ day $)$ & 22.8 \\
\hline 流域面積 $\left(\mathrm{km}^{2}\right)$ & 541.1 \\
\hline 流域人口 & 718,000 \\
\hline 下水道普及率 & $75.6 \%$ \\
\hline
\end{tabular}

\section{（2）印旛沼水質と水生植物の変遷}

印旛沼（図一1）における植生の変遷については，笠 井による長期にわたる観測記録 ${ }^{2)}$ がある。また，公共 用水域水質調査結果が1969年から残っているので，これ らの記録を整理して水質変化と植生遷移とを比較する.

\section{(3) 現地観測}

2004年9月 16 日から11月17日まで，西沼内の一本松下 地点付近に存在したオニビシ群落（浮葉性, 図一1）の 内外 2 地点に観測ステーションを設置し（約200m離れて いる）, 気象, 水質, 波高, 流向・流速の連続観測を 行った. 観測器および測定方法は, 表—2に示すとおり である. また, 観測を行った地点におけるオニビシ群落 の繁茂状況を写真一 1 に示寸。 
表一2 連続観測項目, 使用機器, 測定方法

\begin{tabular}{|c|c|c|c|}
\hline 項目 & 観測機器 & 測定間隔 & 設置水深等 \\
\hline $\begin{array}{l}\text { 水温, 濁度, } \\
\text { D0, } \mathrm{pH}, \mathrm{EC}\end{array}$ & $\begin{array}{l}\text { 多項目水質計, 堀 } \\
\text { 場製作所 U-23 } \\
\text { (1週間毎に交換) }\end{array}$ & $\begin{array}{l}10 \text { 分毎 } \\
\text { 瞬間值 }\end{array}$ & 2 割水深 \\
\hline 風向・風速 & $\begin{array}{l}\text { 風向風速計, デー } \\
\text { ビス社 ウェザー } \\
\text { ウィザードIII }\end{array}$ & $\begin{array}{l}10 \text { 分毎 } \\
120 \text { サンプルの } \\
\text { 平均值 } \\
\end{array}$ & 水面上約 $3 \mathrm{~m}$ \\
\hline 流向・流速 & $\begin{array}{l}\text { 電磁式 } 2 \text { 次元流 } \\
\text { 向・流速計, ア } \\
\text { レック電子 } \mathrm{ACM}- \\
8 \mathrm{M}\end{array}$ & $\begin{array}{l}10 \text { 分毎 } \\
1 \text { 秒間隔 } 30 \text { サン } \\
\text { プル (バーステイ } \\
\text { グモード) }\end{array}$ & 2 割水深 \\
\hline 波高 & $\begin{array}{l}\text { 水圧式波高計, 三 } \\
\text { 洋測器 MWR-II }\end{array}$ & $\begin{array}{l}10 \text { 分毎 } \\
0.1 \text { 秒間隔 } 300 \text { サ } \\
\text { ンプル }\end{array}$ & 8割水深 \\
\hline
\end{tabular}

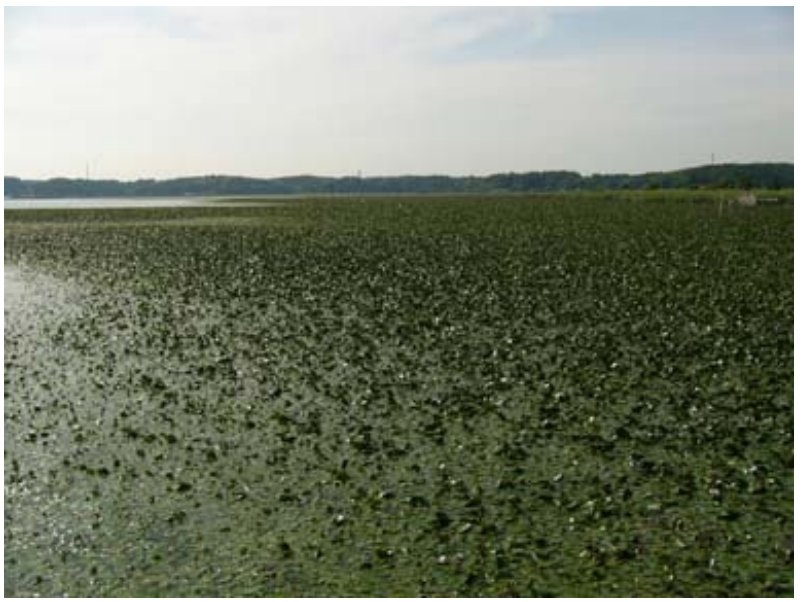

写真一1 オニビシが密生した現場

\section{（4） シミュレーションモデルによる検証}

風波による底泥の巻き上げを考慮した沼内の水質変化 過程をシミュレーションモデルで解析し, 現地観測結果 の検証を行った．沼内の流動計算は，3次元モデル3) を使用した．流動計算を行った格子毎に風波の計算，風 波による底泥巻き上げの計算を行い，風による底泥巻き 上げが沼内水質にどのような影響を与えるかについて, 計算を行った.

植生による巻き上げ抑制のモデル化については，既報 4) と同様に行った. モデル式などについては, 既報 ${ }^{3)}$ 4) を参照のこと. 本研究においては，特に濁りと光の 関係に着目し，植物プランクトンによる遮蔽に加えて, 底泥巻き上げによる濁りに由来する光の散乱を考慮した. このために現地で2005年4月から9月にかけてほぼ半月毎 に17籄所，水深方向に9点で, 同時に同深度において, 濁度計（U-21XD，堀場製作所）および光量子計（LI193SA，LI-COR社製）を用いて，水中での濁度と光量を 計測した. 水中光量は濁度に応じて水深方向に指数関数 的に減衰すると考えられる. 上記の計測毎に得られた濁 りと光との関係から, 計測毎の消散係数を最小二乗法で 求め, さらにこれらの推定值を平均することで, 単位濁 度あたりの光の消散係数を 0.18 とし, 濁りによる光の減
衰を評価した.

計算期間は，現地観測に合わせた．流動については 1 週間の助走計算を行った後に再現計算を開始した. 計算 格子は水平方向に $50 \mathrm{mX} 50 \mathrm{~m}$ ，鉛直方向に 5 層に区分した.

\section{3. 結果}

\section{（1）印旌沼水質と水生植物の変遷}

印旛沼の環境は，1964年の干拓工事により大きく変化 したが，干拓前の印旛沼は，面積2, 900ha，平均水深 $1 \mathrm{~m}$ で透明度が高く水底まで透視できる状態であったことが 記されている ${ }^{2)}$. 植生は湿地性植物, 抽水性植物, 浮 葉性植物, 沈水性植物がそれぞれ安定した群落を形成し ており, 水域では浮葉性のガガブタ, アサザ，ヒシなど の 9 種と沈水性のササバモ，センニンモ，コウガイモな ど 20 種ほどが生育し，沼底のほぼ100\%を被った状況で あった ${ }^{2)}$.

干拓工事により沼は捷水路によりつながれた北沼と西 沼に別れ, 面積 $1,150 \mathrm{ha}$, 水深約 $1.8 \mathrm{~m}$ と面積が約半分, 水深は約 2 倍と現在の形となった. 工事終了後，1972年 に行われた調查では，浮葉性植物が 8 種，沈水性植物は 16 種が認められているものの，1977年の調査では西沼 では浮葉性植物が 4 種, 沈水性植物が 8 種とそれぞれ半 減している.この年の調查で北沼では浮葉性植物が 7 種, 沈水性植物が 14 種発見されており, 北沼に比べて西沼 での水生植物の減衰が顕著に見て取れる. 干拓事業とい う大きな改変の影響を受けた後, 水質悪化に伴い水生植 物種が減少したと考えられる。

笠井によれば，1976年頃から沼周辺の開発による水質 污濁が問題視されるようになったとしているが，公共用 水域水質調查のデータからも，1980年代前半まで水質污 濁が進行していたことが分かる．ただし，1980年代後半 になると，下水道整備に代表される流入河川水の改善が 進み，現在では笠井が指摘した1976年頃に比べて全リン 濃度で1/6程度にまで低下寸るなど，少なくとも流入水 質自体は，水生植物が減衰し始める以前の状態よりも， むしろ良好な状態にまで回復していると言える.

\section{（2）オニビシの底泥巻き上げ抑制効果}

オニビシ群落は，現地観測を始めた段階では，群落内 の観測地点を覆い尽く寸ほどであったが（写真一 1）， 2004年は台風が多く接近したこともあり，9月21日には 強風により岸に寄せられ，9月27日には規模が縮小し， 観測開始時に群落内に位置していた観測地点の周辺にお いてもまばらになった．10月13日の時点では，枯死が進 み，小群落が散在する程度になり，10月20日には周囲に わずかに点在するのみとなった．10月27日にはわずかに 残っていたものも台風により消滅し，水面上には見られ なくなった，計算では，現地で記録されたこのオニビシ 


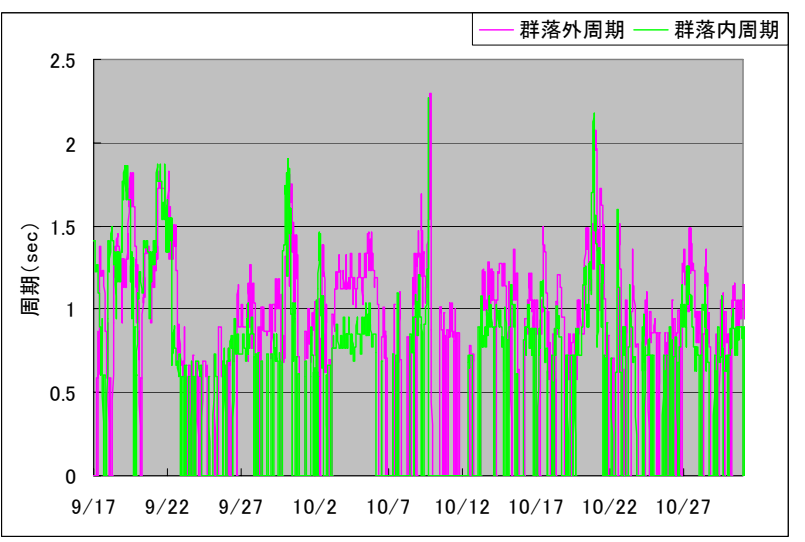

図—2 計算風波周期

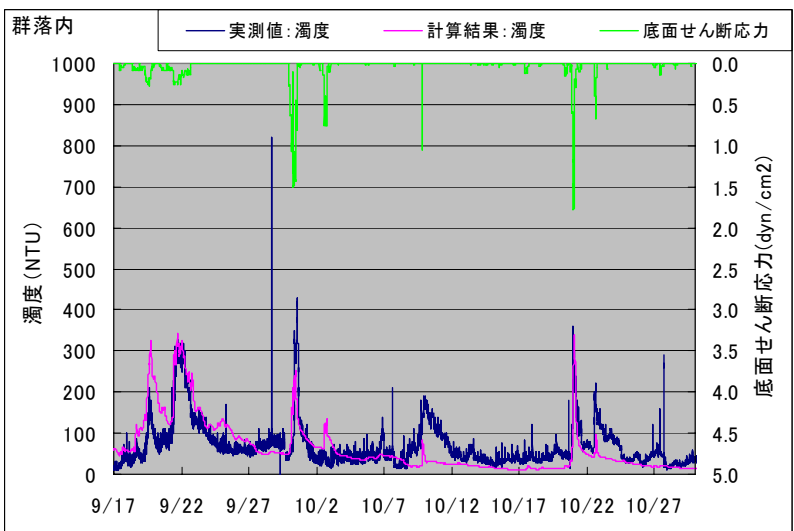

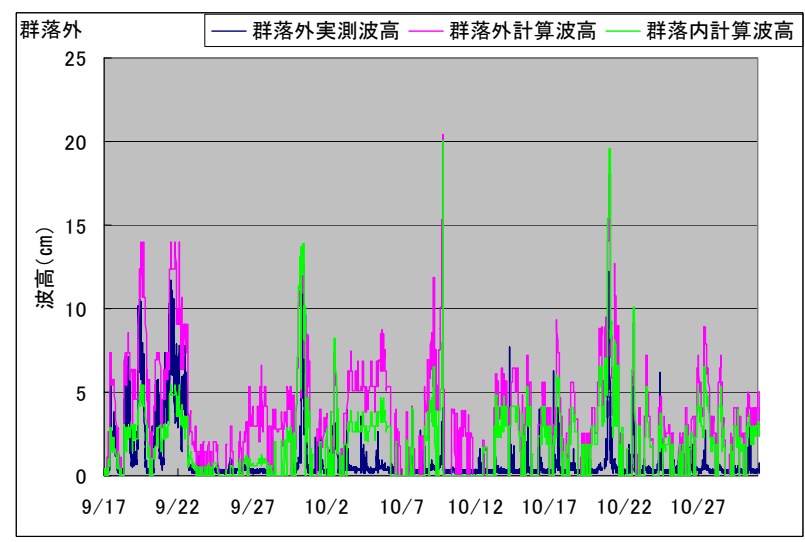

図—3＼cjkstart波高の実測值と計算值との比較

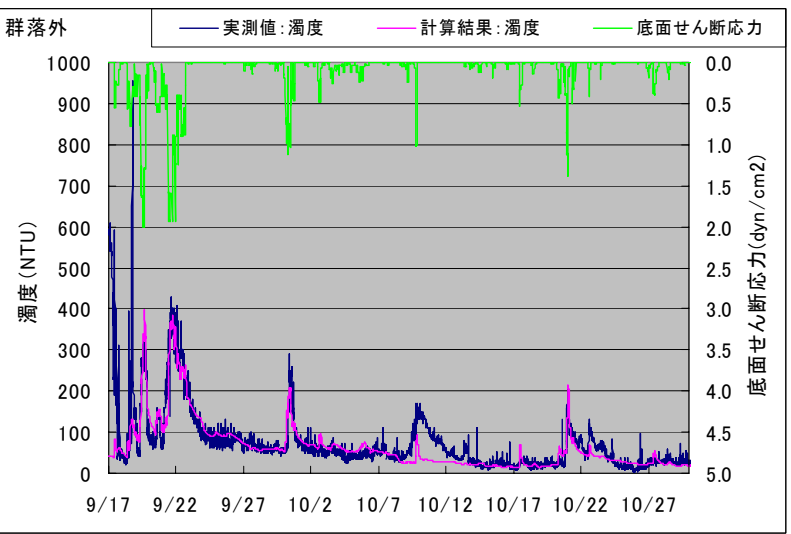

図—4 オニビシ群落内(左)および群落外(右)における観測濁度変化、計算濁度変化および底面せん断応力
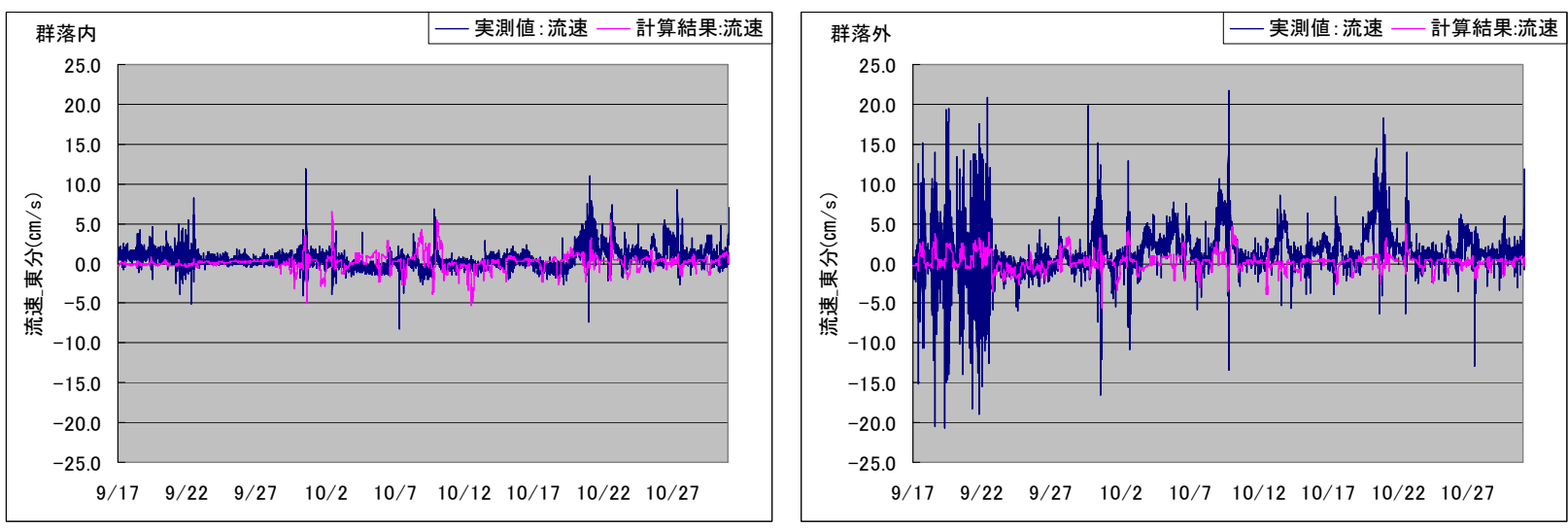

図—5 オニビシ群落内 (左) および群落外 (右) における東方流速成分の実測值と計算值の比較
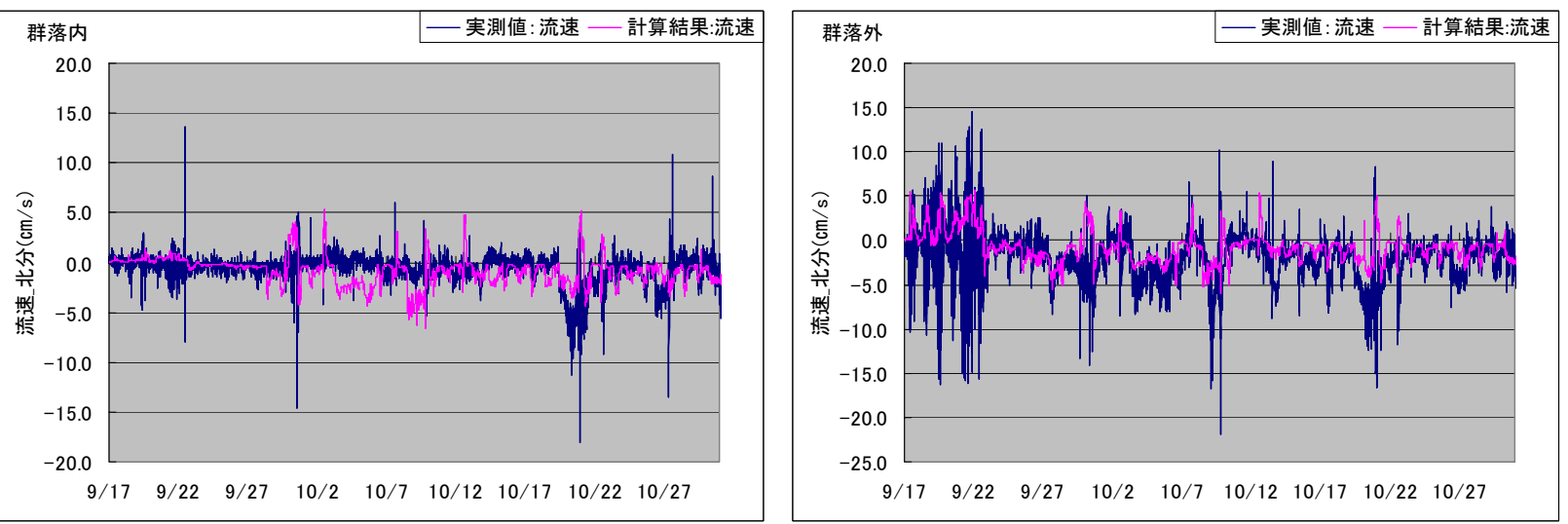

図—6 オニビシ群落内（左）および群落外（右）における北方流速成分の実測值と計算值の比較 
の分布を与えて消波効果を考慮している.

現地観測を開始した直後では，群落の密度も高く，こ のため群落内では消波効果が高かったと考えられる. 図 -2，3に計算および実測による風波関連諸量の変動特 性を示す. 群落密度が高い時期には, 波高が抑制される 計算結果が出ている（群落内での波高測定が不調であっ たため, 波高の測定值については群落外のみ記載してい る.）。波高が抑制されることによる底面剪断応力の抑 制, さらに底泥巻き上げの抑制効果も図—4 と 5 との比 較から見て取れる. 群落内の底面せん断応力の 9 月 20 日 から22日にかけての計算結果を見ると, 強風による底面 せん断応力の上昇が見られるものの, 群落外の計算值に 比べて低くなる傾向が見て取れる. しかし, 群落面積が 減少した後の計算では，消波効果は限定的で，風向き次 第ではむしろ群落内の底面せん断応力の方が大きくなる という計算結果となった。

濁度の測定結果は，オニビシ群落密度が高かった9月 20日から22日にかけては, 群落内での濁度上昇が外に比 ベて抑制されているのに対して, 群落面積の減少後は, 差が減るかむしろ群落内での濁度の方が高くなる結果と なっており，上記の計算結果の妥当性を示していると考 えられる. また濁度の計算結果も測定結果と同様の変化 特性を示している（図一4，5）.

群落内外ともに10月8日から12日にかけて，実測值の 濁度は上昇しているが，計算ではこの傾向が見られない． この理由として，この期間に降雨があり，河川から沼に 濁水が流入したことが挙げられる. 印旙沼における濁り の変化の大部分は，底泥巻き上げにより規定されている ため, 今回の計算では, 流入河川からの懸濁物供給に関 して, 出水時の濁度上昇を特に考慮していないことが不 一致の理由として挙げられる.この期間中, 強い風が連 続的に吹かなかったため, 計算では濁度の上昇が限定的 であったが，測定では河川由来の濁りが到達したために 值が上昇したものと考えられる．底泥巻き上げによる濁 度上昇の際は，粒径が比較的大きい濁質が速やかに沈降 するのに対して, 河川由来の濁りは, 測定位置に到達し た時点で，このような成分がすでに沈降しており，濁質 粒径が小さかったと考えられ，一旦上昇した濁度の低下 が緩やかである。このような特長からも，この期間の実 測と計算との差は，流入河川由来濁水の算定誤差による もので，底泥巻き上げ量の算定誤差によるものではない と考えられる.

流速に関しても，計算，実測值共に群落密度が高い期 間中, 群落内での值が低く, 群落密度の減少と共に, 群 落内外の差が小さくなる傾向を示した（図—5，6）. これら実測および計算結果は, 密生している期間中の才 ニビシ群落の消波効果, 底泥巻き上げ抑制効果を示して いる．群落密度が高い期間の底泥巻き上げ抑制効果は強 い風が吹いた場合にはっきりと見られるが，平常時の濁 度も低く抑えられている（図一4）。

\section{（3）その他の水質項目変化の比較}

オニビシ群落が密生することによる水質への影響とし て，濁りについて見たところであるが，ここでは，その 他の水質項目について，オニビシ群落内外での変動特性 の差について検討する.

富栄養化した湖沼の表層溶存酸素濃度は，植物プラン クトンなどによる光合成のため，昼間に上昇し，場合に よっては，過飽和になる場合がある。また，底層では， 酸素消費により貧酸素化が起こる可能性が高いことが知 られている. 今回の検討では, 溶存酸素については計算 対象としていないので，群落内外での測定結果について 示す（図一7）。群落密度が高い時期において，日周変 化に顕著な違いが見られる，才なわち，群落内外共に昼 間に濃度が上昇し，夜間に低下寸るものの，群落内にお いては，夜間に溶存酸素濃度の低下が著しく，このため 昼間に溶存酸素濃度が上昇しても，群落外に比べて低い 濃度にとどまっている.オニビシは浮葉植物であり, 繁 茂期間中は，水面をおおうため，水面における再曝気が 妨げられる．また，才ニビシの水中根には，多くの微生 物が付着しているため，これらの呼吸により酸素消費が 増加することで, 溶存酸素濃度が低下しやすいと考えら れる．10月13日以降は，群落が消失したためと考えられ るが，群落内外での溶存酸素濃度変化には差がほとんど 見られなくなった. 水面を被っていたオニビシの葉が消 失したことで，群落内外での差がなくなったものと考え られる．これ以降は，底泥巻き上げを含めてオニビシ群 落がもつ沼の水質変化に対する影響がほとんど見られな くなったと考えられる.

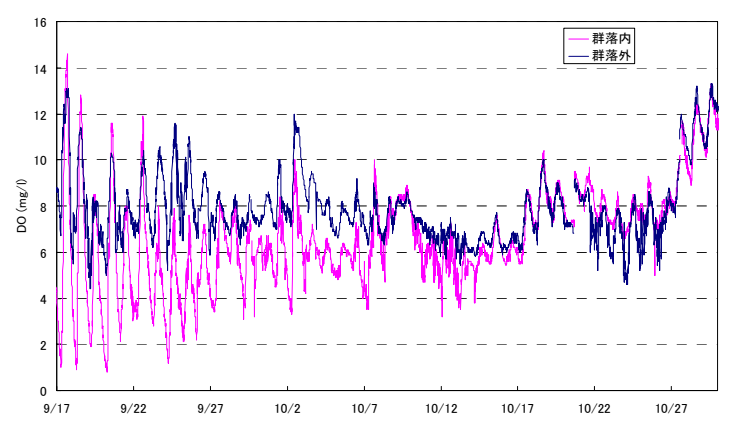

図一7 オニビシ群落内外での溶存酸素変化

\section{4. 考察}

オニビシ群落が有する水流や水質への影響については, 消波効果による底泥巻き上げ抑制，群落の水流に対寸る 抗力による流速の低減効果が計測結果から読みとること ができた。 また，計算からも同様の結果が得られた。 こ れらの結果から，今回検討対象としたオニビシ群落ほど の水生植物の繁茂域が存在すれば，巻き上げに伴う濁度 が周辺に比べて局地的に低下寸ることが分かった. オニ ビシの様な浮葉植物のみならず沈水植物も同様な効果を 
持つことが示されている5).

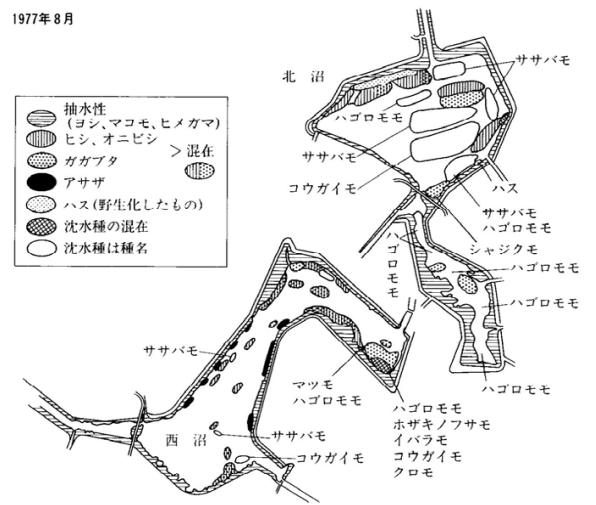

図—8 1977年の北印旛沼での水生植物群落分布 ${ }^{2)}$ 現在の印旛沼には，大規模な沈水植物群落が存在しな いために, 沈水植物に関しては, 今回の検討で行った様 な群落内外での比較計測や検証計算を行うことはできな いが，沈水植物群落がオニビシ同様の巻き上げ抑制効果 を持つと仮定して, 沈水植物群落が存在した沈水植物の 分布域（図—8）に今回の検討で使用したモデルを適用 して水質計算を行い，1977年の沈水植物群落が存在した とした場合の湖底の光状況の現状からの変化を推定した 結果を図一9に示す．光状況は一日の間に大きく変化す るため，7９月について日最大值を抽出し，これらの中 間値をプロットしている.

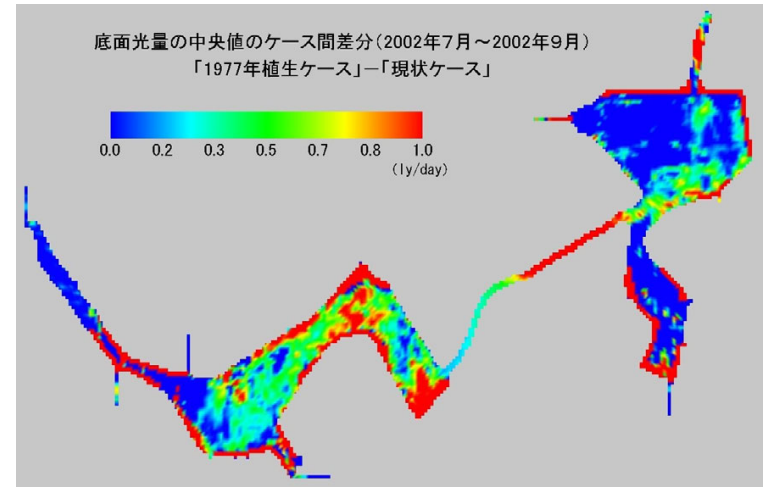

図一9 1977年植生条件での湖底光量の推定増加量

印旛沼では水質悪化に伴い，水生植物（特に沈水植 物）が消滅したが，その原因の一つとして水の濁りが考 えられる. 図一9の結果は, 1977年の植生分布を考えた 場合の, 湖底の現在からの光環境の変化を示している. 1977年の様な植生分布が存在すれば, 湖底の光環境は改 善されると考えられた. しかし, 濁りの低減は顕著であ るが，光は指数関数的に減衰するため，今回の計算から 得られた湖底における光環境改善効果の程度は極めて小 さいものであった.

何らかの方法で十分な光を湖底に届けることで沈水植 物が再生すれば，沈水植物は自ら巻き上げを抑制し，光 環境を改善することで，持続的に生育できると考えられ る. しかし今回の結果は, 現状でも1977年当時と湖底に おける光環境にはあまり差がなく, 光は現在沈水植物が
生育していない理由ではないということを示唆する結果 となった.

ただし，別の見方をすると，(1)沈水植物群落は今回の 計算で仮定したものより底泥巻き上げ抑制効果が高いと 考えられ，今回の結果よりも巻き上げを抑制することが 可能で，そうだとすると1977年当時の湖底での光環境は 現在より良好であった，あるいは(2)1977年当時の底泥は 細粒分が少なく, 今回の計算結果よりも巻き上がりにく かった等の理由のために，実際には光環境が現在より良 かったという可能性を残している．また1977年当時と現 在では濁り以外の水質も異なることから, 今後は, 沈水 植物が繁茂可能な光環境を確保するために必要な条件を さらに追求すると共に水質との関係について検討寸る必 要がある.

\section{5. まとめ}

印旛沼のように一旦富栄養化して水生植物が減退した 湖沼においては，すぐには沈水植物のような水生植物は 再生されないと考えられる. 現在の状況では, オニビシ は生育が可能であり, 濁りを押さえる効果があることが 示されたが，大量に繁茂すると，測定結果に得られたよ うに溶存酸素濃度が低下したり, 漁業に利用されている 印旛沼では航行の障害となるため，環境上あまり好まし くない.このような問題を起こさずに濁りを低減しうる 沈水植物が, 現状で生育できない理由の一つに光制限が 考えられるが，いつどの程度まで光条件を改善すればこ れらが生育可能なのかについて評価することが，再生一 の糸口になると思われる.

謝辞 : 水質調查に関しては, 国土交通省利根川下流河川 事務所ならびに千葉県，特に印旛土木事務所のご担当者 にご協力を頂いた. 記して感謝いたします.

\section{参考文献}

1) Scheffer, M., Ecology of shallow lakes, Kluwer Academic Publishers, 1998.

2) 笠井貞夫, 印旛沼の水生植物の変遷, （山田安彦, 白鳥孝 治，立本英機編，手賀沼・印旛沼），古今書院, 1993.

3) 天野邦彦, 安田佳哉, 鈴木宏幸 : 浅い貯水池における表層 底泥の巻き上げによる水質変化のモデリング，水工学論文 集, 第46巻, pp. 1085-1090, 2002.

4) 天野邦彦, 時岡利和, 対馬孝治 : 浅い湖沼の水質への水生 植物の影響解析, 水工学論文集, 第49巻, pp. 1219-1224, 2005.

5) James, W.F., J. W. Barko and M. G. Butler, Shear stress and sediment resuspension in relation to submersed macrophyte biomass, Hydrobiologia, 515, pp. 181-191, 2004.

(2005. 9. 30受付) 